\title{
ЕКОНОМІЧНА ЕФЕКТИВНІСТЬ ВИКОРИСТАННЯ ЗЕМЕЛЬ ЛІСОГОСПОДАРСЬКОГО ПРИЗНАЧЕННЯ В УМОВАХ ДЕЦЕНТРАЛІЗАЦІї ВЛАДИ
}

\author{
I.A. Опенько \\ кандидат економічних наук \\ Національний університет біоресурсів і природокористування України \\ (Україна, м. Київ; e-mail: ivan_openko@ukr.net) \\ Я.А. Степчук \\ Національний університет біоресурсів і природокористування України \\ (Україна, м. Київ; e-mail: stepchuck.yanina@gmail.com) \\ O.M. Цвях \\ кандидат економічних наук \\ Національний університет біоресурсів і природокористування України \\ (Україна, м. Київ; e-mail: 2231738@i.ua)
}

Економічна ебективність використання земель лісогосподарсъкого призначення є основним критерієм для оцінки теоретичний та практичних рекомендацій у прийнятті управлінсъких рішенъ у сбері природокористування в умовах деиентралізаиї влади. Станом на 2019 рік в Україні було сббормовано 888 об' єднаних територіальних громадах (далі ОТГ) загальною площею - 216,4 тис. кв. км (38,7 \% від загалъної площі України). При існуючій нормативно-правовій системі регулювання біскальних платежів територіальна громада може наповнювати власні бюджети за рахунок комуналъних лісогосподарсъких підприємств, в умовах децентралізаиї влади, через сплату ренти за спеціальне використання лісових ресурсів (кріл деревини з рубок головного користування), податку на прибуток, податку на доходи ббізичних осіб, плати за землю, податок на майно, єдиний податок. За даними Державного агентства лісових ресурсів України, проведені дослідження щодо порівняння загалъних витрат та валового доходу при здійсненні лісового господарства в розрізі державних лісогосподарсъких підприєлств в нашій країні. Розрахована економічна еббективність використання земель лісогосподарсъкого призначення в розрізі областей України. За результатами дослідження нами було визначено економічну ебективність використання земель лісогосподарсъкого призначення. Встановлено позитивний рівенъ використання лісових земель у таких областях, як Київсък, Черкасъка, Житомирсъка, Рівненсъка, Хмелънииъка, Чернігівсъка, Закарпатсъка, Чернівецъка, Івано-Франківсъка, Тернопілъсъка, Сумсъка, Вінницъка, Полтавсъка, Кіровоградсъка. Водночас в таких областях, як Донецъка, Запорізъка, Лугансъка, Миколаївсъка, Одесъка, Харківсъка, Херсонсъка, Дніпропетровсъка, Лъвівсъка, Волинсъка використання земель лісогосподарсъкого призначення є неприбутковим, нерентабельним та завдає економічних збитків лісогосподарсъким підприємствам. Основними причинами таких обставин на нашу думку $є$ несприятливі лісотаксаиійні умови вирощування деревини, типи грунтів, природно-кліматичні умови регіону тощо.

Ключові слова: економічна ебективність, використання земель, землі лісогосподарсъкого призначення, децентралізація, лісистість, рентабелъність, окупність затрат, валовий дохід, чистий прибуток.

Постановка проблеми. 32014 року Україна досягла значних успіхів у регіональному розвитку, територіальній реформі та децентралізації. Кабінет Міністрів розпочав багаторівневу реформу управління, що включає широкий процес децентралізації. За короткий проміжок часу були вжиті успішні кроки до досягнення муніципальних об'єднань, більшої фріскальної, адміністративної та політичної децентралізації. Цей процес доповнюється Державною стратегією регіонального розвитку на 20152020 роки [1; 2].

Станом на 2019 рік в Україні було сорормовано 888 об'єднаних територіальних громадах (далі ОТГ) загальною площею - 216,4 тис. кв. км (38,7\% від загальної площі України). В межах цих ОТГ проживають 9,1 млн осіб ( $26 \%$ від загальної чисельності населення України). Водночас ці ОТГ набувають нових повноважень у здійсненні місцевого самоврядування, отриму- 
ють нові повноваження та додаткові ресурси для ї безпосереднього виконання згідно норм Бюджетного кодексу, зокрема, у сорерах освіти, охорони здоров'я, соціального захисту, житлово-комунального господарства [3].

При існуючій нормативно-правовій системі регулювання фіскальних платежів територіальна громада може наповнювати власні бюджети за рахунок комунальних лісогосподарських підприємств, в умовах децентралізації влади, через сплату ренти за спеціальне використання лісових ресурсів (крім деревини з рубок головного користування), податку на прибуток, податку на доходи фрізичних осіб, плати за землю, податок на майно, єдиний податок [4]. Саме тому розрахунок економічної ефективності використання земель в умовах децентралізації влади є надзвичайно важливим етапом розвитку ОТГ.

Аналіз останніх досліджень і публікацій. Значний науковий внесок у розвиток досліджень які стосуються еколого-економічної ролі земель лісогосподарського призначення щодо формування сталого розвитку навколишнього середовища здійснили такі вчені, як Г.Н. Висоцький, Г.Ф. Морозов, С.А. Генсірук, Б.Г. Іваницький, О.I. Фурдичко, I.М. Лицур, А.М. Дейнека, Т.А. Кіслова, Я.В. Коваль, І.Я. Антоненко, В.С. Бондар, О.А. Голуб, О.І. Дребот, В.К. Добровольський, П.В. Васільєв, І.В. Воронін, О.О. Сенкевич, Ю.М. Марчук та інші.

Виділення невирішених раніше частин загальної проблеми. Водночас, зважаючи на існуючі зміни, дерегуляції фрнкцій управління земельними ресурсами, спричинені легітимними реформами в нашій країні, зокрема, створенням територіальних громад, розрахунок економічної ефективності використання земель лісогосподарського призначення в умовах децентралізації влади є необхідною умовою для прийняття продуктивних управлінських рішень в сорері природокористування та охорони навколишнього середовища.

Метою дослідження $є$ розрахунок економічної ефективності використання земель лісогосподарського призначення в умовах децентралізації влади. Для досягнення поставленої мети були визначені відповідні завдання:

- визначити чистий дохід державних лісогосподарських підприємств від використання земель лісогосподарського призна-чення;

- за показниками ефективності використання вкладень визначити економічну ефрективність використання земель лісогосподарського призначення в умовах децентралізації влади.

Матеріали та методи. Питання економічної ефективності в лісовому господарстві та агролісомеліоративному виробництві розглянуті в різних наукових джерелах. Практично всі вони, головним чином, описують методику визначення економічної ефективності, обгрунтування величини економічного ефекту окремих лісогосподарських заходів, доцільності проектування окремих видів робіт тощо [5].

Водночас економічне обгрунтування щодо ефективності заходів щодо охорони та захисту земель лісогосподарського призначення в загальному регламентуються фрормулою 1 [5].

$$
\mathrm{E}=\mathrm{B}-\mathrm{C},
$$

де $\mathrm{E}$ - економічний ефрект від заходів щодо охорони та захисту земель лісогосподарського призначення; В - загальний обсяг втрат у лісовому господарстві, яких вдалося запобігти (не допустити) за рахунок проведення заходів щодо захисту лісів; C — собівартість робіт щодо захисту лісових масивів.

Узагальнюючим показником ефективного використання земель лісогосподарського призначення слугує показник кількості валової продукції, отриманої за рік у розрахунку на 100 га лісового фонду, визначається за фрормулою (2) $[6$, C. 83].

$$
\Pi=\frac{(\mathrm{A}+\mathrm{H}+\mathrm{B}+\mathrm{B}+\Gamma+\mathrm{Z}) \times 100}{P},
$$

де П - загальний обсяг валової продукції на 100 га лісового фронду у грошовому еквіваленті; А — продукція від головного використання деревини у таксових цінах; $\mathrm{H}$ - зміна запасу деревини поточного виробництва; Б - продукція від рубок догляду у відпускних цінах; В - продукція отримана внаслідок побічного (другорядного, нецільового) використання земель лісогосподарського призначення; $\Gamma$ - додаткова продукція отримана із прилеглих сільськогосподарських угідь, зважаючи на захисні властивості лісу; Д - продукція мисливського господарства; Р — площа лісового фонду.

Викладення основного матеріалу. Економічна ефрективність використання земель лісогосподарського призначення є основним критерієм для оцінки теоретичний та практичних рекомендацій у прийнятті управлінських рішень у сорері природокористування в умовах децентралізації [7-9].

За даними Державного агентства лісових ресурсів України, нами були проведені дослідження щодо порівняння загальних витрат та валового доходу при здійсненні лісового господарства в розрізі державних лісогосподарських підприємств в нашій країні. В якості інформаційної бази був використаний звіт про 
виконання виробничого плану по лісовому господарству за 2017 рік (форма 10-ЛГ).

Загальні витрати лісогосподарських підприємств щодо використання земель лісогосподарського призначення по Україні, включають наступні статті видатків [10-16]:

- витрати на лісове господарство. Найбільша частка витрат на лісове господарство в Україні спостерігається в Київській області (54\% від загальної суми витрат на лісове господарство в нашій державі), натомість наступними областями за відповідною статтею витрат слідують Житомирська (5\% від загальної суми витрат на лісове господарство по Україні) та Рівненська (5\%) області. Як бачимо лісогосподарські підприємства Київської області є беззаперечними лідерами у фінансуванні лісового господарства при здійсненні виробничої діяльності хоча площа лісових земель в регіоні є не найбільшою;

- витрати на захисні лісонасадження;

- витрати на збереження природно-заповідного фонду. У структурі витрат на збереження природно-заповідного фонду в Україні найбільшу частку займають адміністративні витрати $(43,11 \%)$ та затрати на загально-виробничі витрати $(39,41 \%)$.

- витрати на спеціальне використання лісових ресурсів та інші заходи.

Водночас доходи лісогосподарських підприємств від здійснення своєї виробничої діяльності враховують наступні надходження:

- від руху лісопродукції внаслідок рубок, пов'язаних з веденням лісового господарства, інших рубок та ліквідації захаращенності (4 739 698,4 тис. грн): від розробки хлистів (стовбур поваленого дерева, очищений від гілок, верхівки і пневої частини); реалізації деревини (по цінах реалізації без ПДВ); заготовлі ялинок із хвороста; інші надходження.

- від руху лісопродукції внаслідок рубок головного користування (4 088183 тис. грн): від розробки хлистів; реалізації деревини (по цінах реалізації без ПДВ); заготовлі ялинок із хвороста; інші надходження.

- від руху лісопродукції на нижньому складі (13 682 410,2 тис. грн): від розробки хлистів; реалізації деревини (по цінах реалізації без ПДВ); заготовлі ялинок із хвороста; інші надходження.

Серед окреслених позицій надходжень від використання земель лісогосподарського призначення найбільшу частку в Україні займають доходи від руху лісопродукції на нижньому складі $-72 \%$ загального обсягу надходжень; доходи від руху лісопродукції внаслідок рубок, пов'язаних з веденням лісового господарства, інших рубок та ліквідації захаращенності зай- мають другу позицію - 15\%; надходження які поступають від руху лісопродукції внаслідок рубок головного користування становлять $13 \%$ загального обсягу.

Згідно аналізу доходів від використання земель лісогосподарського призначення державними підприємствами в розрізі областей України слідує що в таких областях як Київська, Черкаська, Хмельницька, Тернопільська, Рівненська, Житомирська, Сумська, Вінницька, Волинська головна частка надходжень зумовлена від руху лісопродукції на нижньому складі (рис. 1).

Наступним етапом нашого дослідження було співставлення загальних витрат та валового доходу від використання земель лісогосподарського призначення та визначення чистого прибутку лісогосподарських підприємств (табл. 1, рис. 2).

Розрахунок економічної ефективність використання земель лісогосподарського призначення нами здійснювався на основі відносних показників, які характеризують ефективність використання вкладень та показників доходів і витрат а саме:

- загальні витрати лісогосподарських підприємств на одиницю площі лісових земель, грн/га;

- валовий дохід лісогосподарських підприємств на одиницю площі лісових земель, грн/га;

- чистий прибуток отриманий лісогосподарськими підприємствами у розрахунку на 1 га, грн/га (таблиця 2, рис. 3).

За результатами розрахунків ефрективності використання земель слідує що найприбутковіше лісогосподарське виробництво в Україні у розрахунку на 1 га лісових земель, зосереджено в Київській, Черкаській, Хмельницькій, Чернівецькій, Тернопільській, Рівненській, Житомирській, Чернігівській областях;

- коефіцієнт ефективності капітальних вкладень (рентабельність лісового господарства), \% (рис. 4);

Найбільш рентабельне лісогосподарське виробництво визначається у Черкаській, Тернопільській, Хмельницькій, Чернівецькій, Чернігівській, Рівненській областях термін окупності витрат яких становить до 9 років (рис. 5).

У Кіровоградській, Полтавській, Сумській, Вінницькій областях лісове господарство є низькорентабельним із періодом окупності капітальних витрат 24-40 років.

Висновки. Таким чином за результатами дослідження нами було визначено економічну ефективність використання земель лісогосподарського призначення. Встановле- 


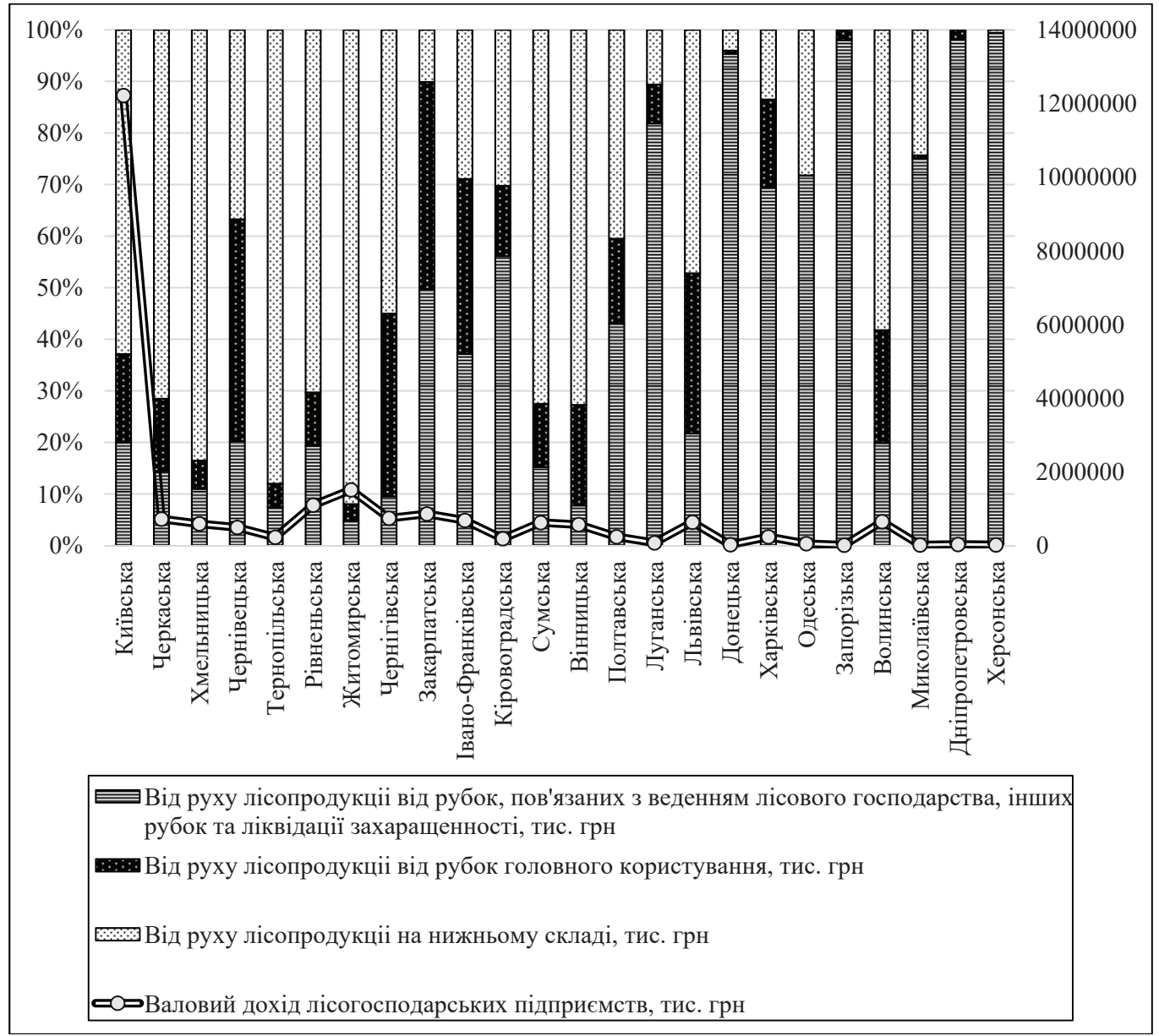

Рис. 1. Діаграма структури доходів від використання земель лісогосподарсъкого призначення в розрізі областей в Україні Джерело: створено автором за даними Державного агентства лісових ресурсів України — формою № 10-ЛГ (2017 рік).

Розрахунок чистого прибутку від використання земель лісогосподарського призначення в Україні станом на 2017 р.

\begin{tabular}{|l|c|c|c|}
\hline $\begin{array}{l}\text { Назва адміністративно- } \\
\text { територіальної одиниці }\end{array}$ & $\begin{array}{c}\text { Загальні витрати } \\
\text { лісогосподарських } \\
\text { підприсмств, тис. грн }\end{array}$ & $\begin{array}{c}\text { Ұаловий дохід від } \\
\text { лісогосподарського } \\
\text { виробництва, тис. грн }\end{array}$ & $\begin{array}{c}\text { прйибуок } \\
\text { отриманий } \\
\text { підприсмствами, тис. грн }\end{array}$ \\
\hline \hline Київська & $\mathbf{2}$ & $\mathbf{3}$ & $\mathbf{4}$ \\
\hline Черкаська & 11420268,3 & 12215991,4 & 159027,7 \\
\hline Жлтомирська & 561186,9 & 720214,6 & 136537,1 \\
\hline Рівненська & 1375972,7 & 1512509,8 & 114115,5 \\
\hline Хмельницька & 984274,7 & 1098390,2 & 78738,8 \\
\hline Чернігівська & 513493,9 & 592232,7 & 77704,1 \\
\hline Закарпатська & 664555,1 & 742259,2 & 63932,5 \\
\hline Чернівецька & 795612,9 & 859545,4 & 61734,9 \\
\hline
\end{tabular}


Закінчення таблиці 1

\begin{tabular}{|l|c|c|c|}
\hline \multicolumn{1}{|c|}{$\mathbf{1}$} & $\mathbf{2}$ & $\mathbf{3}$ & $\mathbf{4}$ \\
\hline \hline Івано-Франківська & 625742,6 & 683133,4 & 57390,8 \\
\hline Тернопільська & 182374,7 & 226164,5 & 43789,8 \\
\hline Сумська & 605885,0 & 623082,5 & 17197,5 \\
\hline Вінницька & 555833,1 & 569837,0 & 14003,9 \\
\hline Полтавська & 229982,2 & 238334,4 & 8352,2 \\
\hline Кіровоградська & 180392,1 & 187882,8 & 7490,7 \\
\hline Донецька & 31680,2 & 23638,5 & $-8041,7$ \\
\hline Запорізька & 22015,9 & 12391,2 & $-9624,7$ \\
\hline Луганська & 86565,0 & 74470,1 & $-12094,9$ \\
\hline Миколаївська & 29717,1 & 15998,1 & $-13719,0$ \\
\hline Одеська & 66668,1 & 51102,5 & $-23565,6$ \\
\hline Харківська & 259895,9 & 236454,7 & $-24536,5$ \\
\hline Херсонська & 43002,3 & 18465,8 & $-24542,1$ \\
\hline Дніпропетровська & 54523,1 & 29981,0 & $-26722,8$ \\
\hline Львівська & 661388,5 & 634665,7 & $-62897,6$ \\
\hline Волинська & 712207,9 & 649310,3 & . \\
\hline
\end{tabular}

Джерело: розраховано автором за даними Державного агентства лісових ресурсів України — формою № 10-ЛГ (станом на 2017 рік).

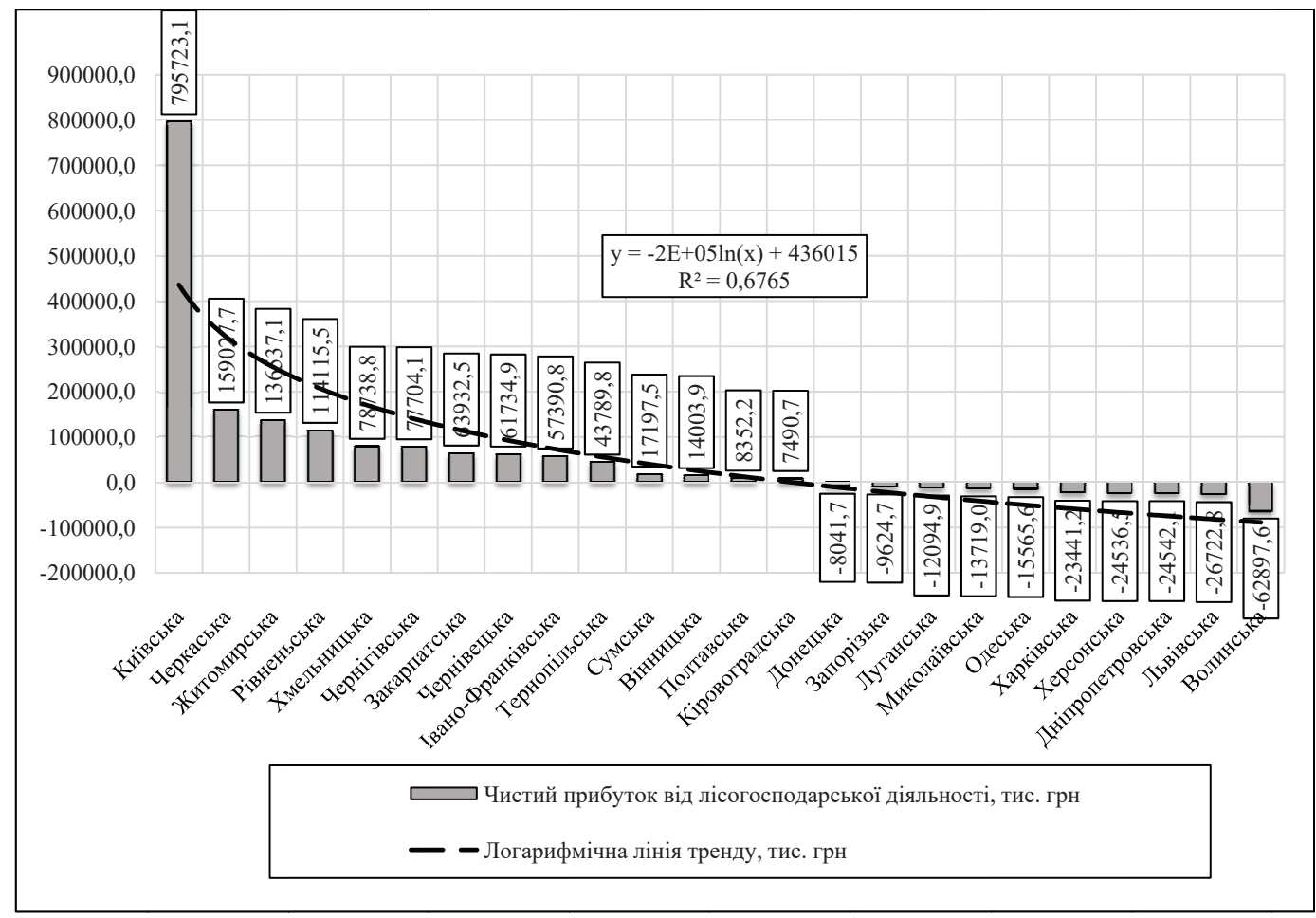

Рис. 2. Діаграма прибутковості використання земель лісогосподарсъкого призначення державними підприємствами в розрізі областей в Україні

Джерело: розраховано автором за даними Державного агентства лісових ресурсів України формою № 10-ЛГ (станом на 2017 рік). 
Таблиия 2

Розрахунок ефективності використання земель лісогосподарського призначення в Україні

\begin{tabular}{|c|c|c|c|}
\hline $\begin{array}{l}\text { Назва адміністративно- } \\
\text { територіальної одиниці }\end{array}$ & \begin{tabular}{|c} 
Загальні витрати \\
лісогосподарських \\
підпристст на одиницю \\
площі лісових земель
\end{tabular} & $\begin{array}{c}\text { Валовий дохід } \\
\text { лісогосподарських } \\
\text { підприємств на одиницю } \\
\text { площі лісових земель }\end{array}$ & $\begin{array}{c}\text { Прибуток отриманий } \\
\text { лісогосподарькими } \\
\text { підприємствами у } \\
\text { розрахунку на } 1 \text { га земель } \\
\text { лісогосподарського } \\
\text { призначення }\end{array}$ \\
\hline & грн/га & грн/га & грн/га \\
\hline Київська & 18075,8 & 19335,2 & 1259,5 \\
\hline Черкаська & 1700,6 & 2182,5 & 481,9 \\
\hline Житомирська & 1288,1 & 1415,9 & 127,8 \\
\hline Рівненська & 1240,4 & 1384,2 & 143,8 \\
\hline Хмельницька & 1835,9 & 2117,4 & 281,5 \\
\hline Чернігівська & 961,2 & 1073,6 & 112,4 \\
\hline Закарпатська & 1174,3 & 1268,7 & 94,4 \\
\hline Чернівецька & 1709,5 & 1953,5 & 244,0 \\
\hline Івано-Франківська & 1027,2 & 1121,4 & 94,2 \\
\hline Тернопільська & 935,7 & 1160,4 & 224,7 \\
\hline Сумська & 1346,1 & 1384,3 & 38,2 \\
\hline Вінницька & 1513,7 & 1551,8 & 38,1 \\
\hline Полтавська & 843,4 & 874,0 & 30,6 \\
\hline Кіровоградська & 1007,8 & 1049,6 & 41,8 \\
\hline Донецька & 158,7 & 118,4 & $-40,3$ \\
\hline Запорізька & 185,9 & 104,7 & $-81,3$ \\
\hline Луганська & 255,7 & 219,9 & $-35,7$ \\
\hline Миколаївська & 241,4 & 130,0 & $-111,4$ \\
\hline Одеська & 308,2 & 236,3 & $-72,0$ \\
\hline Харківська & 644,7 & 586,6 & $-58,2$ \\
\hline Херсонська & 286,7 & 123,1 & $-163,6$ \\
\hline Дніпропетровська & 288,8 & 158,8 & $-130,0$ \\
\hline Львівська & 995,8 & 955,5 & $-40,2$ \\
\hline Волинська & 1065,9 & 971,7 & $-94,1$ \\
\hline
\end{tabular}

Джерело: розраховано автором за даними Державного агентства лісових ресурсів України - формою № 10-ЛГ (на 2017 рік). 


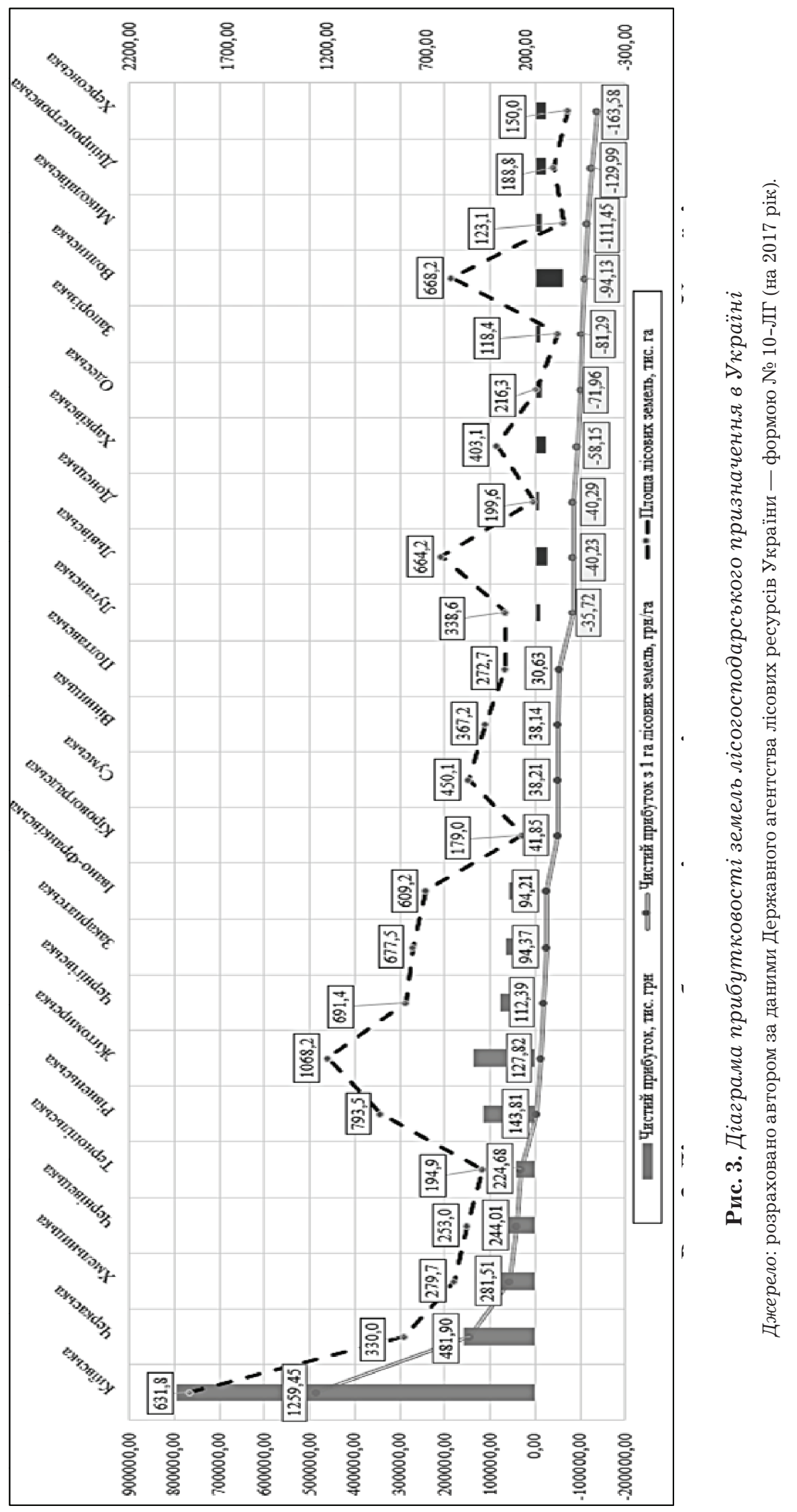




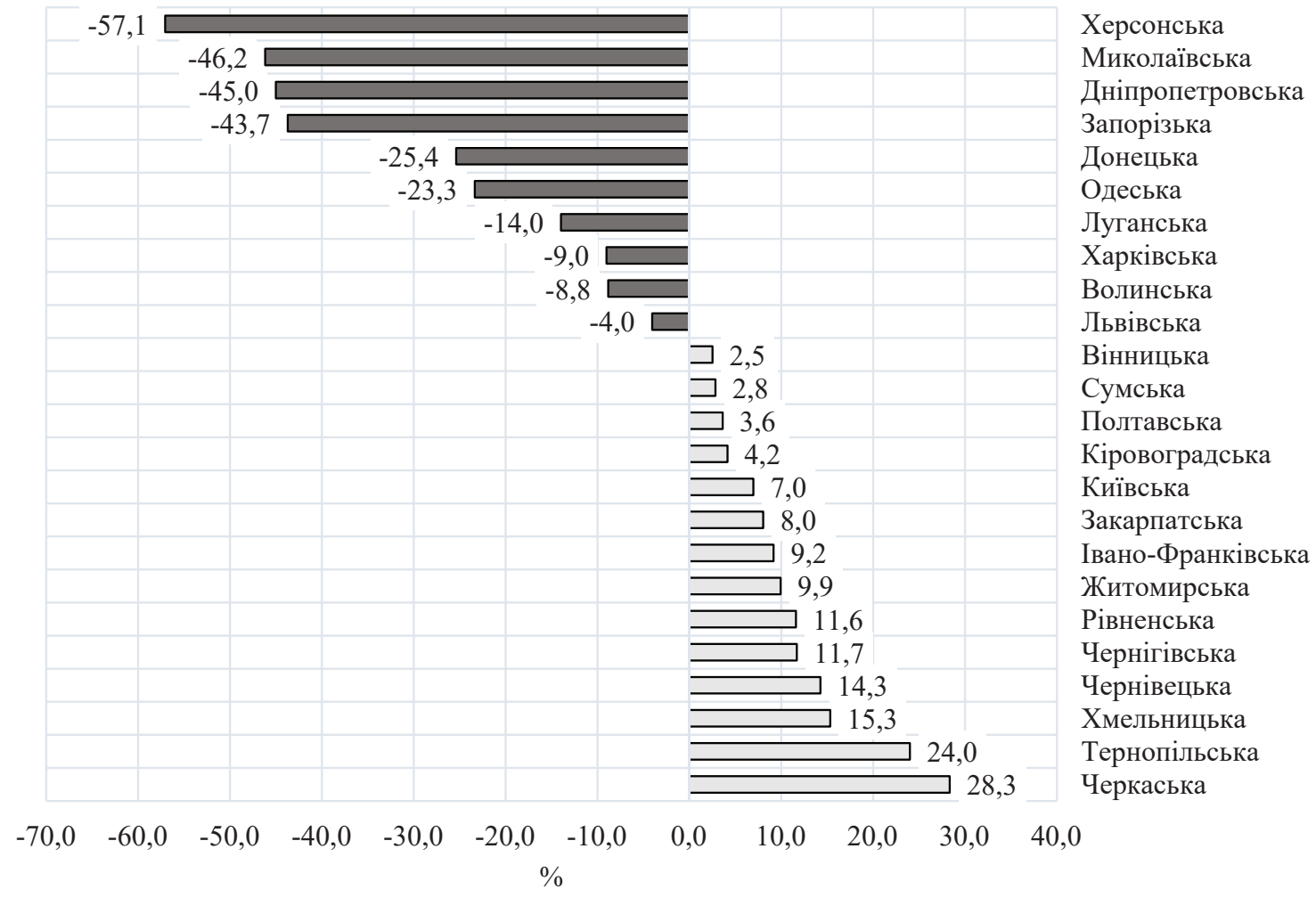

Рис. 4. Діаграма рентабельності лісогосподарсъких підприємств в розрізі областей в Україні Джерело: розраховано автором за даними Державного агентства лісових ресурсів України — формою № 10-ЛГ (2017 рік).

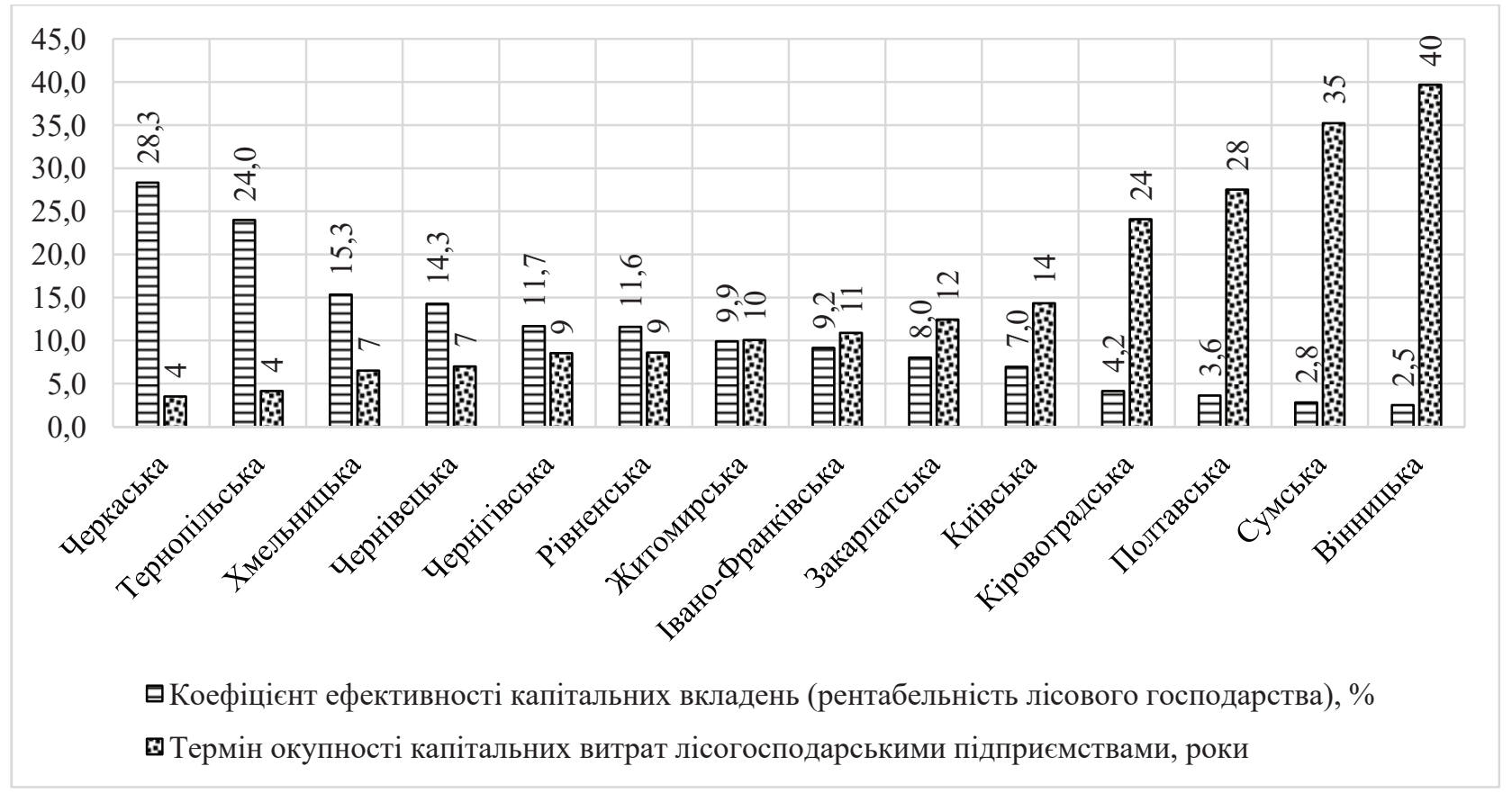

Рис. 5. Діаграма прибутковості земелъ лісогосподарсъкого призначення в Україні Джерело: розраховано автором за даними Державного агентства лісових ресурсів України — формою № 10-ЛГ (на 2017 рік). 
но позитивний рівень використання лісових земель у таких областях, як Київська, Черкаська, Жћитомирська, Рівненська, Хмельницька, Чернігівська, Закарпатська, Чернівецька, Івано-Франківська, Тернопільська, Сумська, Вінницька, Полтавська, Кіровоградська.

Водночас в таких областях, як Донецька, Запорізька, Луганська, Миколаївська, Одеська,
Харківська, Херсонська, Дніпропетровська, Львівська, Волинська використання земель лісогосподарського призначення є неприбутковим, нерентабельним та завдає економічних збитків лісогосподарським підприємствам. Основними причинами таких обставин на нашу думку є несприятливі лісотаксаційні умови вирощування деревини, типи грунтів, природнокліматичні умови регіону тощо.

\section{СПИСОК ВИКОРИСТАНИХ ДЖЕРЕЛ}

1. Опенько I.А. Кореляційний аналіз впливу існуючої системи державного управління на використання земель лісогосподарського призначення в Україні. Економіка та держава. № 7. 2019. С. 55-62.

2. OECD. Maintaining the Momentum of Decentralisation in Ukraine, OECD Multi-level Governance Studies, OECD Publishing, Paris, 2018. [Електронний ресурс]. Режим доступу: https://read.oecd-ilibrary.org/urban-rural-and-regional-development/maintaining-the-momentum-of-decentralisation-inukraine_9789264301436-en\#page69

3. Децентралізація. Про об’єднання громад. Інфографіка [Електронний ресурс]. Режим доступу: https://decentralization.gov.ua/gromadas/gallery

4. Оборська А.Е., Жила А.С., Матейко I.М., Жила Т.Б. Комунальні лісогосподарські підприємства і місцеві громади. Інформаційний довідник. К. «ЦП Компринт». 2017. 110 с.

5. Воронин И.В., Сенкевич А.А., Бугаев В.А. Экономическая эфффективность в лесохозяйственном и лесомелиоративном производствах. «Лесная промышленность», М. 1975. 176 с.

6. Воронин И.В., Васильев П.В., Судачков Е.Я. Экономика лесного хозяйства СССР. Изд. 3-е, перераб. и доп. М.: «Лесная промышленность», 1978. 264 с.

7. Шевченко О.В., Опенько І.А. Теоретичні передумови раціонального сільськогосподарського землекористування. Збалансоване природокористування. 2017. № 3. С. 126-130.

8. Шевченко О.В., Опенько I.А., Цвях О.М. Економічні передумови чергування культур як спосіб запобігання деградації агроландшафту. Землеустрій, кадастр і моніторинг земель. 2017. № 2. С. 58-65.

9. Tsvyakh O., Openko I. Main directions of urban land optimization in Kiev agglomeration. Baltic Surveying International Scientific Journal. 2017. Vol.6_1. P. 60-65.

10. Цвях O.M., Опенько І.А. Промислові території, як просторовий базис оптимізації використання земель в місті Києві. Землеустрій, кадастр і моніторинг земель. 2017. № 1. С. 83-91.

11. Опенько I.А., Шевченко О.В., Цвях О.М. Аналіз наукових-методичних підходів до грошової оцінки земельних ділянок із полезахисними лісовими насадженнями. Збалансоване природокористування. 2016. № 4. C. $137-142$.

12. Опенько I. А., Євсюков Т. О. Удосконалення обліку кількості та якості земель під полезахисними лісовими насадженнями в кадастрово-реєстраційній системі. Збалансоване природокористування. 2014. № 3. C. $106-112$

13. Опенько I. А., Євсюков Т. О. Землі під полезахисними лісовими насадженнями: сучасний стан, проблеми, шляхи вирішення. Збалансоване природокористування. 2014. № 1. С.125-131.

14. Опенько I. А. Порівняльний аналіз оприлюднення земельно-кадастрових відомостей у зарубіжних країнах та Україні. Землеустрій, кадастр і моніторинг земель. 2013. № 3. С. 80-87.

15. Ievsiukov T., Openko I. An Inventory Database, Evaluation and Monitoring of Especially Valuable Lands at Regional Level in Ukraine. Elsivier, Procedia - Social and Behavioral Sciences, «GEOMED 2013» The 3rd International Geography Symposium June 10-13, 2013 Kemer, Antalya - Turkey. Access mode: http://www.sciencedirect.com/science/article/pii/S1877042814016619.

16. Євсюков Т.О., Опенько I.А. Моніторинг особливо цінних земель із застосування технологій ДЗЗ та ГІС. Вісник Львівського державного аграрного університету: екноміка АПК. 2013. № 20 (2). С. $231-242$.

\section{Інформація про авторів}

Опенько Іван Анатолійович - кандидат економічних наук, доцент кафедри геодезії та картографії, Національний університет біоресурсів та природокористування України (Україна, 03040, м. Київ, вул. Васильківська, 17, навчальний корпус 6.; e-mail: ivan_openko@gmail.com).

Степчук Яніна Анатоліївна - лаборант кафедри геодезії та картографії, Національний університет біоресурсів та природокористування України (Україна, 03040, м. Київ, вул. Васильківська, 17, навчальний корпус 6.; e-mail: stepchuck.yanina@gmail.com).

Цвях Олег Миколайович - кандидат економічних наук, викладач кафредри земельного кадастру, Національний університет біоресурсів та природокористування України (Україна, 03040 , м. Київ, вул. Васильківська, 17, навчальний корпус 6.; e-mail: 2231738@i.ua). 
I.A. Openko

$\mathrm{PhD}$ in Economics

National University of Life and Environmental Sciences of Ukraine (Ukraine, Kyiv; e-mail: ivan_openko@ukr.net)

Ya.A. Stepchuk

National University of Life and Environmental Sciences of Ukraine (Ukraine, Kyiv; e-mail: stepchuck.yanina@gmail.com)

O.M. Tsvyakh

$\mathrm{PhD}$ in Economics

National University of Life and Environmental Sciences of Ukraine

(Ukraine, Kyiv; e-mail: 2231738@i.ua)

\section{ECONOMIC EFFICIENCY OF LAND FOREST USING IN THE CONDITIONS OF DECENTRALIZATION}

The economic efficiency of using the lands of forest management is the main criterion for assessing the theoretical and practical recommendations in making management decisions in the field of nature management in conditions of decentralization of power.

As of 2019, 888 united territorial communities with a total area of 216.4 thousand square $\mathrm{km}$ were formed in Ukraine (38.7\% of the total area of Ukraine). Under the current regulatory system of regulation of fiscal payments, the territorial community can fill its own budgets at the expense of municipal forestry enterprises, in the conditions of decentralization of power, through payment of rent for special use of forest resources (except timber from logging), income tax, income tax individuals, land payments, property tax, single tax.

According to the State Agency of Forest Resources of Ukraine, studies have been conducted on the comparison of total expenditures and gross income in the implementation of forestry in the context of state forest enterprises in our country. The economic efficiency of using the lands of forest management in terms of regions of Ukraine is calculated. According to the results of the study, we determined the economic efficiency of the use of forest land. Positive level of forest land use was established in such areas as Kyiv, Cherkasy, Zhytomyr, Rivne, Khmelnytsky, Chernihiv, Transcarpathian, Chernivtsi, Ivano-Frankivsk, Ternopil, Sumy, Vinnytsia, Poltava, Kirovograd. At the same time, in such areas as Donetsk, Zaporizhia, Lugansk, Mykolaiv, Odessa, Kharkiv, Kherson, Dnipropetrovsk, Lviv, Volyn, the use of forest land is unprofitable, unprofitable and causes economic losses to forestry enterprises. In our opinion, the main causes of such circumstances are the unfavorable forest-toxication conditions of growing timber, types of soils, natural and climatic conditions of the region, etc.

Keywords: economic efficiency, use of land, forest land, decentralization, forestry, profitability, cost recovery, gross income, net profit.

\section{REFERENCES}

1. Openko, I.A. (2019). Korelyatsiynyy analiz vplyvu isnuyuchoyi systemy derzhavnoho upravlinnya na vykorystannya zemel' lisohospodars'koho pryznachennya v Ukrayini [Correlation analysis the effects of current public administration system on forest land use in Ukraine]. Ekonomika ta derzhava [Economy and State], 7. 55-62. (In Ukr.)

2. OECD (2018). «Maintaining the Momentum of Decentralisation in Ukraine, OECD Multi-level Governance Studies», OECD Publishing, Paris. [Electronic source]. URL: https://read.oecd-ilibrary.org/ urban-rural-and-regional-development/maintaining-the-momentum-of-decentralisation-in-ukraine_9789264301436-en\#page69 (date of accesse: 11.04.2019).

3. The official site of the Detsentralizatsiya (2019). About community associations. Infographics. [Electronic source]. URL: https://decentralization.gov.ua/gromadas/gallery (In Ukr.)

4. Obors'ka, A.E., Zhyla, A.S., Matejko, I.M. and Zhyla, T.B. (2017). Komunal'ni lisohospodars'ki pidpryiemstva $i$ mistsevi hromady [Public forest enterprises and local communities]. Kyiv: TsP Komprynt. 110. (In Ukr.)

5. Voronin, I.V., Senkevich, A.A. and Bugaev, V.A. (1975). Ekonomicheskaya effektivnost'v lesokhozyaystvennom i lesomeliorativnom proizvodstvakh [Economic efficiency in forestry and forest reclamation production]. Moscow: «Lesnaya promyshlennost'». 176. (In Russ.)

6. Voronin, I.V., Vasilyev, P.V. and Sudachkov, E.Y. (1978). Ekonomika lesnogo khozyaystva SSSR [Forest Economics of the USSR]. Moscow: «Lesnaya promyshlennost'». 264. (In Russ.)

7. Shevchenko, O.V. \& Openko, I.A. (2017). Teoretychni peredumovy ratsional'noho sil's'kohospodars'koho zemlekorystuvannya [Theoretical prerequisites for rational agricultural land use]. Zbalansovane pryrodokorystuvannia [Balanced nature using], 3. 126-130. (In Ukr.) 
8. Shevchenko, O.V. Openko, I.A. and Tsvyakh O.M. (2017). Ekonomichni peredumovy cherhuvannya kul'tur yak sposib zapobihannya dehradatsiyi ahrolandshaftu [Economic preconditions for alternating crops as a way to prevent degradation of the agro-landscape]. Zemleustrij, kadastr i monitorynh zemel' [Land cadastre and land monitoring], 2. 58-65. (In Ukr.)

9. Tsvyakh, O. \& Openko, I. (2017). Main directions of urban land optimization in Kiev agglomeration, Baltic Surveying International Scientific Journal, 6 (1). 60-65.

10. Tsvyakh, O.M. \& Openko, I.A. (2017). Promyslovi terytoriyi, yak prostorovyy bazys optymizatsiyi vykorystannya zemel' v misti Kyyevi [Industrial territories as a spatial basis for optimizing the use of land in the city of Kiev], Zemleustrij, kadastr $i$ monitorynh zemel', [Land cadastre and land monitoring], 1. 83-91. (In Ukr.)

11. Openko, I.A., Shevchenko, O.V. and Tsvyakh, O.M. (2016). Analiz naukovykh-metodychnykh pidkhodiv do hroshovoyi otsinky zemel'nykh dilyanok iz polezakhysnymy lisovymy nasadzhennyamy. [Analysis of scientific and methodical approaches to the monetary valuation of land with field-protective forest plantations]. Zbalansovane pryrodokorystuvannia [Balanced nature using], 4. 137-142. (In Ukr.)

12. Openko, I.A. \& Ievsiukov, T.O. (2014). Udoskonalennya obliku kil'kosti ta yakosti zemel' pid polezakhysnymy lisovymy nasadzhennyamy v kadastrovo-reyestratsiyniy systemi [Improving accounting quantity and quality of land for shelter forest plantations in the cadastral registration system]. Zbalansovane pryrodokorystuvannia, [Balanced nature using], 3. 106-112. (In Ukr.)

13. Openko, I.A. \& Ievsiukov, T.O. (2014). Zemli pid polezakhysnymy lisovymy nasadzhennyamy: suchasnyy stan, problemy, shlyakhy vyrishennya [Lands under field-protective forest plantations: current state, problems, solutions]. Zbalansovane pryrodokorystuvannia [Balanced nature using], 1. $125-131$. (In Ukr.)

14. Openko, I.A. (2013). Porivnyal'nyy analiz oprylyudnennya zemel'no-kadastrovykh vidomostey u zarubizhnykh krayinakh ta Ukrayini [A comparative analysis of the publication of land cadastral data in foreign countries and Ukraine], Zemleustrij, kadastr $i$ monitorynh zemel' [Land cadastre and land monitoring], 3. 80-87. (In Ukr.)

15. Ievsiukov, T. \& Openko, I. (2013). An Inventory Database, Evaluation and Monitoring of Especially Valuable Lands at Regional Level in Ukraine. Elsivier, Procedia — Social and Behavioral Sciences, «GEOMED 2013» The 3rd International Geography Symposium June 10-13, Kemer, Antalya, Turkey. [Electronic source]. URL: http://www.sciencedirect.com/science/article/pii/S1877042814016619 (date of accesse: 05.03.2019).

16. Ievsiukov, T. \& Openko, I. (2013). Monitorynh osoblyvo tsinnykh zemel' iz zastosuvannya tekhnolohiy DZZ ta GIS [Monitoring of particularly valuable lands using GIS and GIS technologies]. Visnyk L'vivs'koho derzhavnoho ahrarnoho universytetu: eknomika APK [Bulletin of Lviv State Agrarian University: Economics of AIC], 20 (2). 231-242. (In Ukr.)

\footnotetext{
Authors

Openko Ivan Anatoliiovych - PhD in Economics, Associate Professor, Department of Geodesy and Cartography, National University of Bioresources and Environmental Management of Ukraine (Ukraine, 03040, Kyiv, 17 Vasylkivska St.; e-mail: ivan_openko@gmail.com).

Stepchuk Yanina Anatoliivna - Laboratory Assistant, Department of Geodesy and Cartography, National University of Bioresources and Environmental Management of Ukraine (Ukraine, 03040, Kyiv, 17 Vasylkivska St.; e-mail: stepchuck.yanina@gmail.com).

Tsviakh Oleh Mykolaiovych - PhD in Economics, Lecturer in the Department of Land Cadastre, National University of Bioresources and Environmental Management of Ukraine (Ukraine, 03040, Kyiv, 17 Vasylkivska St.; e-mail: 2231738@i.ua).
} 